International Journal of Current Advanced Research

ISSN: O: 2319-6475, ISSN: P: 2319 - 6505, Impact Factor: SJIF: 5.995

Available Online at www.journalijcar.org

Volume 6; Issue 3; March 2017; Page No. 2564-2570

DOI: http://dx.doi.org/10.24327/ijcar.2017.2570.0050

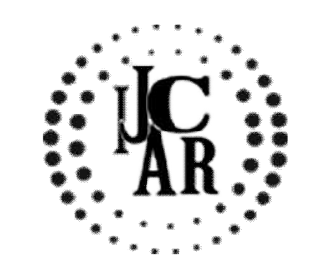

Research Article

\title{
POSSIBILITY OF USING CONTROL CARDS IN THE IMPROVEMENT OF MEDICAL SERVICES QUALITY
}

\author{
Beata Detyna*1 $^{* 1}$ and Jerzy Detyna ${ }^{2 *}$
}

\begin{abstract}
${ }^{1}$ The Angelus Silesius University of Applied Sciences in Walbrzych, The Institute of Natural and Technical Studies, ul. Zamkowa 4, 58-300 Walbrzych, Poland

${ }^{2}$ Wroclaw University of Science and Technology, Department of Mechanics, Materials Science and Engineering, ul.

Smoluchowskiego 25, 50-370 Wroclaw, Poland
\end{abstract}

\section{A R T I C L E I N F O}

\section{Article History:}

Received $18^{\text {th }}$ December, 2016

Received in revised form $16^{\text {th }}$ January, 2017

Accepted $26^{\text {th }}$ February, 2017

Published online $28^{\text {th }}$ March, 2017

\section{Key words:}

Statistical Process Control, Control Cards, Health Care, Hospital, Quality \begin{abstract}
A B S T R A C T
Methods of statistical process control (SPC) provide objective methods of quality control in every manufacturing process, regardless of whether it is manufacture of articles or services. Systematic study of the processes should provide knowledge about their performance and the sources of the deviations from the norm. This article is an attempt to prove the thesis that it is possible to use control charts for variable (continuous) and attribute data in healthcare facilities. It is a collection of examples of cards $\bar{x}-R$ (mean and range) and type C cards.
\end{abstract}

Copyright $(2017$ Beata Detyna and Jerzy Detyna. This is an open access article distributed under the Creative Commons Attribution License, which permits unrestricted use, distribution, and reproduction in any medium, provided the original work is properly cited.

\section{INTRODUCTION}

The methods of statistical process control (SPC) provide objective means of quality control in every process of production, regardless of whether it is a production of, or provision of services (Thor et al., 2007). The systematic study of the processes should provide for the knowledge of their performance and the emergence of the sources of deviations from the norm (Greiner, Li, Kawachi, Hunt, \& Ahluwalia, 2004; Munechika, Sano, Jin, \& Kajihara, 2014).

This article is an attempt to proving the argument that it is possible to use control charts for variables data (continuous and discrete) in health care establishment. It is a collection of examples of the cards (mean and spread) and $C$ type cards. SPC tools, including control charts can be used to measure the degree of conformity of supplied materials, services, processes and products of the previously agreed specifications (e.g. standards in medicine) (Benneyan, Lloyd, \& Plsek, 2003; Detyna, 2011; Detyna \& Detyna, 2011; Henderson et al., 2008). These techniques are based on selecting a representative, random sample of single and the "population" (e.g. patients, staff physicians, nurses, administrators, etc.) or input/output process (e.g. to groups of costs, revenues, etc.).

*Corresponding author: Jerzy Detyna, Wroclaw University of Science and Technology, Department of Mechanics, Materials Science and Engineering, ul. Smoluchowskiego 25, 50-370 Wroclaw, Poland
After analyzing the sample it is possible to take decisions on the current state of the process, its inputs and outputs. Statistical process control is used mostly in industrial enterprises. However, with proper selection of key parameters would allow to analyze the processes taking place in health care establishment (Baji, García-Goñi, Gulácsi, Mentzakis, \& Paolucci, 2015; Coast, 2009; Litva et al., 2002; Perkins, Subramanian, \& Christakis, 2015; Różewski, Zaikin, Kusztina, \& Tadeusiewicz, 2011; Subramanian, 2004).

Some changes in the quality of products or services belong to the randomized category, e.g. an emotional state doctor, a staff absence, a failure of transport, etc. If in the process there are only random change, is recognized that the process is in a stable state (statistical control). An important factor is the variability of specific processes, what affects the total variability and revealed in their testing (Antoñanzas, JuárezCastelló, \& Rodríguez-Ibeas, 2016; Hewett, Watson, Gallois, Ward, \& Leggett, 2009; Martin, Leslie, Minion, Willars, \& Dixon-Woods, 2013; Mascia, Angeli, \& Di Vincenzo, 2015). Keeping control charts is based on information from a random sampling during the process (Detyna, 2011, 2015). They are a graphic illustration of the measurement process in time, allowing to identify problems. In the fixed, regular intervals of samples are taken (e.g. a few examples of the product, to assess the degree of satisfaction with the services of a select group of patients, etc.). There is measurement for all manufactured products/services (Dahlgaard, Pettersen, \& Park, 2011; Lee, Lee, \& Olson, 2012). 
For each sample are calculated statistical measures: the arithmetic mean, median, standard deviation, etc., the desired characteristics (e.g. the estimated cost of stay in hospital) (Hamrol \& Mantura, 2008; Kwietniewski, Heimeshoff, \& Schreyögg, 2016; Rappange, van Exel, \& Brouwer, 2016; Timmerman, Verrall, Clatney, Klomp, \& Teare, 2010). The graph presented the results of the process, the overall mean value of the process and control limits (acceptable tolerances). The upper and lower control limits (UCL - Upper Control Limit, LCL - Lower Control Limit) is created by adding (subtracting) a number of standard deviations (typically \pm 3 standard deviations) to the average overall. These limits should be customized to changing needs and requirements. They represent the desired range of variability. Exceeding the limits indicates that the process is not stable and must be corrected (Flynn, Louviere, Peters, \& Coast, 2010). The control card allows you to determine the effect of normal or unusual reasons for the process. It serves, among others to:

- Distinction, when we are dealing with a natural, and when the results of the extraordinary distribution in the sample;

- Detection when the controlled process to affect normal, and when the specific cause of variation;

- $\quad$ Rating whether the process is adjusted (under statistical control) (Łańcucki, 2003; Muhlemann, Oakland, \& Lockyer, 1992; Thompson \& Koronacki, 2001; Thomas M Wickizer, Franklin, Fulton-Kehoe, Turner, \& et al., 2004).

Each process is unique and it should be considered in the implementation of statistical methods for quality improvement. Basic control charts are selected depending on the type of data collected. There are cards for data variables (continuous) and attribute (discrete).

The most commonly used cards for variables are:

- Card (the average value of the process);

- Card (spread in the sample) exploring the range of variability of the process;

- Card (standard deviation);

- Card (middle and spread).

- The cards for discrete data that result from alternative assessment is the most common:

- Card (control, of defective products in the process);

- Card (the number of non-conformity, in samples with a fixed number);

- Card (the number of defects per unit, with the same number of samples);

- Card (the number of defects per unit, when sample sizes are different) (Muhlemann et al., 1992).

One of the purposes control cards is to help assessing whether the process is under statistical control. Out of control is when measurements go beyond the line of permissible variation. Seven consecutive points above or below the center line on the card may indicate that there was a special reason (outside the system) (Curtis et al., 2006; Giorgio, Filippini, \& Masiero, 2015; Holli, Laippala, Ojala, \& Pitkänen, 1999; Lurie, Merrens, Lee, \& Splaine, 2002; Nair et al., 2012; T M Wickizer, Franklin, Plaeger-Brockway, \& Mootz, 2001).

The sample characteristics needed to produce control cards allow you to define so-called. ability of the process. Process capability analysis can be conducted only when the process is regulated (Thompson \& Koronacki, 200; Thomas M Wickizer et al., 2004). Ability of qualitative indicators, also called performance indicators used to determine how the test process is able to meet the quality requirements of the organization. The process capability index can be written as the quotient of the width of the tolerance and the limits of variability.

It is preferred to maintain this ratio at the highest level. If the value is below unity is a company receives a signal of increasing the share of products (services), inconsistent with requirements (Guthrie, Love, Fahey, Morris, \& Sullivan, 2005; Hinckley, 2003; Kusztina, Zaikin, \& Tadeusiewicz, 2010; Manning et al., 2007).

\section{METHODOLOGY}

Exemplification of the use of control charts in the process of improving the quality of medical services was based on information from a random sampling, during the certain processes in the selected Polish Specialist Hospital. We gathered research material for patients waiting for admission to the Admissions Section of the Chamber, the time of their expectations for the first test diagnostic and data concerning the level of patient satisfaction with medical services.

Samples were fixed in regular intervals. The research material to the type $\bar{x}-R$ of control charts for the waiting time in admission room and waiting time to first diagnostic test came from a study that lasted 21 days and included 10 randomly selected patients each day. Individuals were reported waiting times of patients. Data on the type of $C$ control charts related to the level of patient satisfaction with medical services and derived from the survey. Patients in an alternative (well, bad) evaluated five areas for action hospital: how to organize work in a hospital, the competence of doctors, nurses work, the sanitary conditions in hospitals and hospital equipment and medical equipment. $C$ cards allowed for discrepancies in the ratio of the sample to the sample size, the sample size was every day constant. The study sample consisted of 10 randomly selected patients discharged from hospital that day for a 27 working days. Survey questionnaires were analyzed by identifying those in which one response was negative. For each sample were obtained in the appropriate statistical measures (arithmetic mean, variance). The graphs show the results of the survey process, the overall mean value of the process and control limits (acceptable tolerances). The paper presents an analysis of the processes under investigation capabilities.

\section{RESULTS}

\section{Cards for the variables $X$ - mean and $R$ - Range}

Assessing the quality of processes in health services from the perspective of patients, we can look at patient waiting times for admission to the ward from the admission room or to the first diagnostic test performed. The data for control cards are derived from surveys measuring the level of satisfaction of patients at the selected hospital. The study lasted 21 days and included 10 randomly selected patients each day. The waiting time cards $\bar{x}-R$ for admission room (Fig. 1) show that the average for this variable was close to 32 minutes. In 11 days, with 21 patients waiting longer. Average for the second day is about 45 minutes to eight-41 minutes, and for fifteen, 
eighteen and twenty - 40 minutes. In nine days, the average waiting times were shorter, but the shortest time is about 20 minutes. There is a clear disproportion between the spreads for each day on the $R$ card. It would be to consider the causes of this fact. It could have caused such an exceptionally large number of patients waiting for adoption. Analysis Zones A / $\mathrm{B} / \mathrm{C}$ was successful (Table 1), but the quality of the process capability indices (Table 2) indicate a need for improvement, so as to approach the set norms. The process was not set centrally, what is evident in Figure 2. case. Disproportion between the specification limits and process capability to meet these requirements can be seen in Figure 4.

\section{Control Alternative Cards}

Data on the level of patient satisfaction from medical services, we can gain from different types of polls. In the questionnaires the level of patient satisfaction can used control charts:

X-bar and R Chart; variable: Waiting time for emergency room [min] Histogram of Means

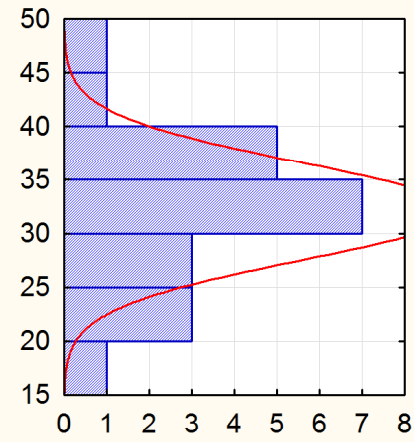

Histogram of Ranges

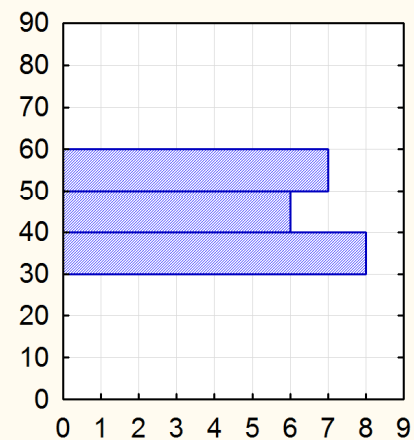

X-bar: 32.067 (32.067); Sigma: 14.406 (14.406); n: 10.

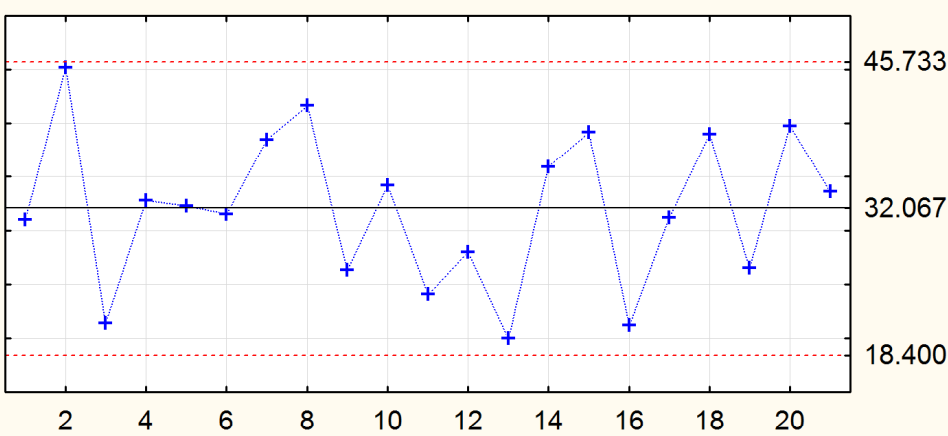

Range: 44.333 (44.333); Sigma: 11.482 (11.482); n: 10.

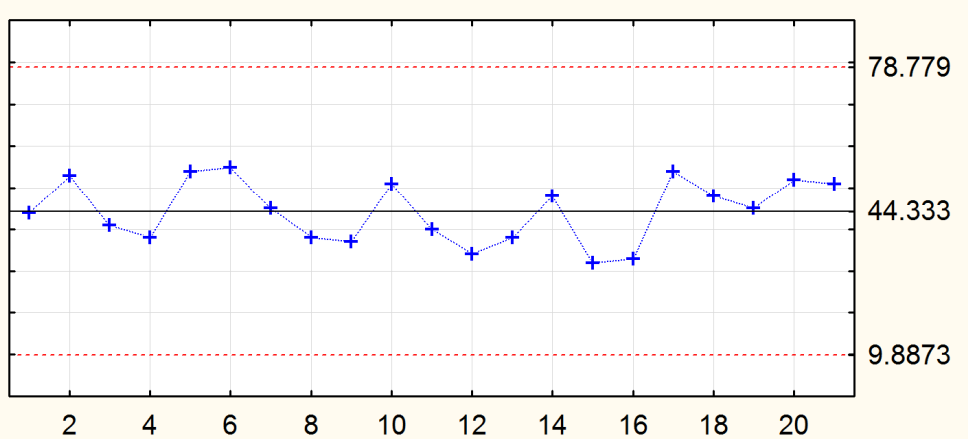

Fig. 1 Control charts of average waiting time of patients in admission room of the Specialist Hospital. Source: own work in the Statistica program of "StatSoft" Company.

Table $1 \mathrm{~A} / \mathrm{B} / \mathrm{C}$ Zones analysis for a variable: patients average waiting time in admission room of the Specialist Hospital. Source: own work in the Statistica program of "StatSoft" Company.

\begin{tabular}{ccc}
\hline $\begin{array}{c}\text { Zones A/B/C: } \\
\text { 3.000/2.000/1.000 *Sigma } \\
\text { Tests for special causes (runs } \\
\text { rules) }\end{array}$ & $\begin{array}{c}\text { Waiting time for emergency room } \\
\text { [min]; Run Tests X-bar Chart } \\
\text { Center line: 32.067 Sigma: 4.55 }\end{array}$ \\
\cline { 2 - 3 } & From sample & To sample \\
\hline $\begin{array}{c}\text { 9 samples on same side of center } \\
6 \text { samples in row in/decreasing } \\
14 \text { samples alternating up \& } \\
\text { down }\end{array}$ & OK & OK \\
$\begin{array}{c}\text { oK } \\
\text { or } 3 \text { samples in Zone A or } \\
\text { beyond }\end{array}$ & OK & OK \\
4 or 5 samples in Zone B or & OK & OK \\
beyond & OK & OK \\
15 samples in Zone C & OK & OK \\
8 samples beyond Zone C & OK & OK \\
\hline
\end{tabular}

A similar rating can be made studying patient waiting times to first diagnostic test (Fig. 3). Evaluation of zones A / B / C is shown in Table 3. The indicators $C_{p}$ and $C_{p k}$ of ability are given in Table 4. Indicators are smaller than unity, what means that activities in the process require further thought. Accepted standards (specification limits) were not met in this

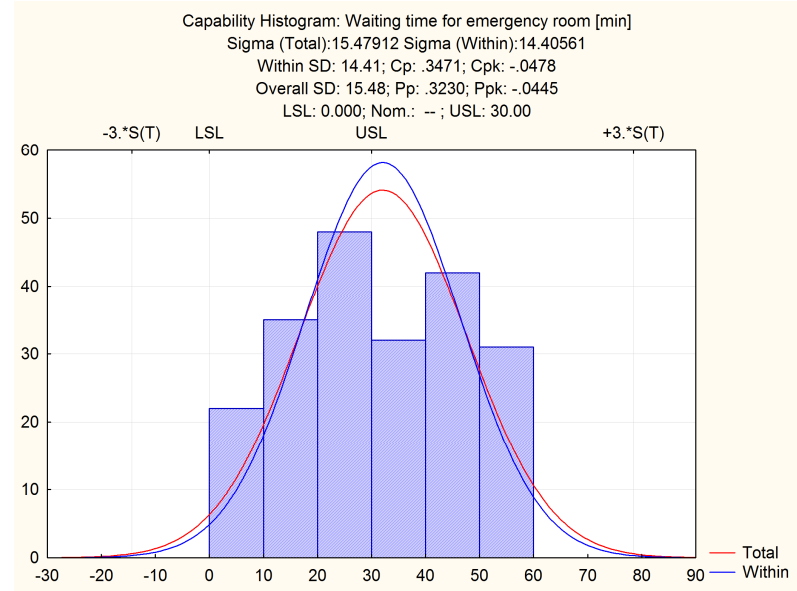

Fig. 2 Graphical illustration of the process capability indices for average waiting time of patients in admission room of the Specialist Hospital. Source: own work in the Statistica program of "StatSoft" Company. 
- $\quad$ Numeric, if in the survey responses are expressed in a numerical scale, such as Likert scale $(1-5)$ card $\bar{x}-s$;

- $\quad$ Alternate, if the response in the survey are expressed in a binary (yes, no) $P, U$ card for not equinumerous samples, $C$ card for equinumerous samples.

Table 2 Analysis of process capability for the patients average waiting time in admission room of the Specialist Hospital. Source: own work in the Statistica program of "StatSoft" Company.

\begin{tabular}{|c|c|}
\hline $\begin{array}{c}\text { Capability index } \\
\text { Within-sample sigma }=\text { R-bar/d2 }\end{array}$ & $\begin{array}{c}\text { Waiting time for emergency } \\
\text { room [min]; Set } 0 \text { (Default } \\
\text { Set) } \\
-3.000 * \text { Sigma }=-11.15 \\
3.000 * \text { Sigma }=75.29\end{array}$ \\
\hline & $\begin{array}{l}\text { Value } \\
\end{array}$ \\
\hline $\begin{array}{l}\text { Lower Specyfication Limit } \\
\text { Nominal Specyfication }\end{array}$ & 0.000 \\
\hline Upper Specyfication Limit & 30.000 \\
\hline CP ( potential capability) & 0.347 \\
\hline CR (capability ratio) & 2.881 \\
\hline CPK (demonstrated excellence) & -0.048 \\
\hline CPL (lower capability index) & 0.742 \\
\hline CPU ( upper capability index) & -0.048 \\
\hline $\mathrm{K}$ ( non-centering correction) & 1.138 \\
\hline
\end{tabular}

Table 4 Analysis of process capability for patients waiting time for the first diagnostic test in the Specialist Hospital. Source: own work in the Statistica program of "StatSoft" Company.

\begin{tabular}{|c|c|}
\hline $\begin{array}{c}\text { Capability index } \\
\text { Within-sample sigma }=R- \\
\text { bar } / \mathrm{d} 2\end{array}$ & $\begin{array}{c}\text { Waiting time for emergency } \\
\text { room }[\text { min]; Set } 0 \text { (Default Set) } \\
-3.000 * \text { Sigma }=-3.575 \\
3.000 * \text { Sigma }=32.261\end{array}$ \\
\hline & Value \\
\hline $\begin{array}{l}\text { Lower Specyfication Limit } \\
\text { Nominal Specyfication }\end{array}$ & 0.000 \\
\hline Upper Specyfication Limit & 20.000 \\
\hline CP ( potential capability) & 0.558 \\
\hline CR (capability ratio) & 1.792 \\
\hline CPK (demonstrated excellence) & 0.316 \\
\hline CPL (lower capability index) & 0.800 \\
\hline CPU ( upper capability index) & 0.316 \\
\hline $\mathrm{K}$ ( non-centering correction) & 0.434 \\
\hline
\end{tabular}

On the grounds of the poll, there was decided to delete the $\mathrm{C}$ control card. The respondents (patients) have assumed in alterative way (good, bad):

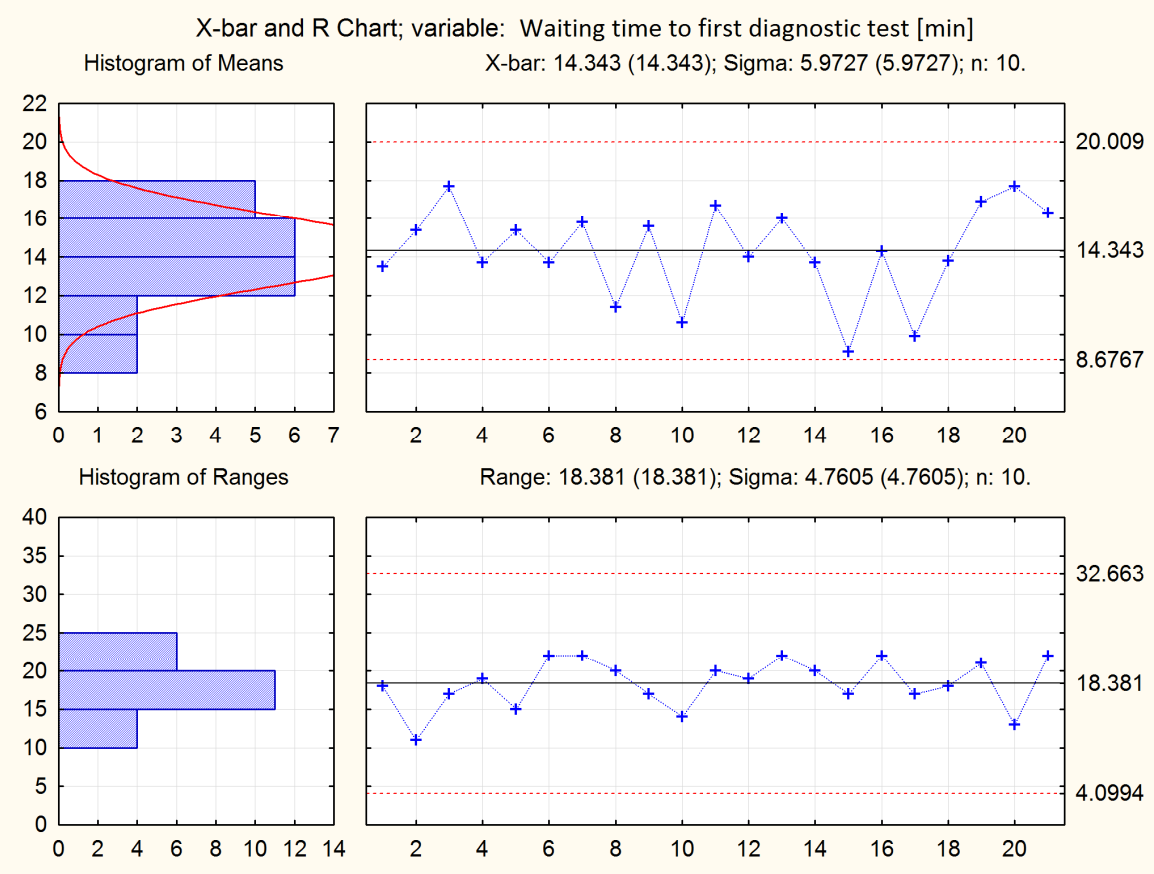

Fig. 3 Control charts of average waiting times of patients for the first diagnostic test in the Specialist Hospital. Source: own work in the Statistica program of "StatSoft" Company.

Table $3 \mathrm{~A} / \mathrm{B} / \mathrm{C}$ Zones analysis for a variable: patients waiting time for the first diagnostic test in the Specialist Hospital. Source: own work in the Statistica program of "StatSoft" Company.

\begin{tabular}{ccc}
\hline $\begin{array}{c}\text { Zones A/B/C: 3.000/2.000/1.000 } \\
\text { *Sigma } \\
\text { Tests for special causes (runs } \\
\text { rules) }\end{array}$ & $\begin{array}{c}\text { Waiting time for emergency room } \\
\text { [min]; Run Tests X-bar Chart } \\
\text { Center line: 14.343 Sigma: 1.889 }\end{array}$ \\
\cline { 2 - 3 } & From sample & To sample \\
\hline 9 samples on same side of center & OK & OK \\
6 samples in row in/decreasing & OK & OK \\
14 samples alternating up \& down & OK & OK \\
2 or 3 samples in Zone A or & 15 & 17 \\
beyond & OK & OK \\
4 or 5 samples in Zone B or beyond & OK & OK \\
15 samples in Zone C & OK & OK \\
\hline 8 samples beyond Zone C & &
\end{tabular}

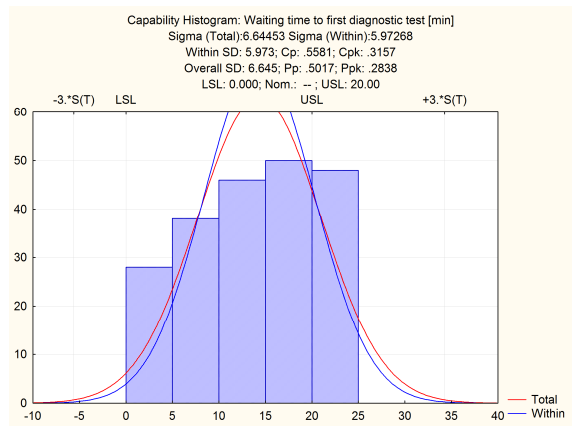

Fig. 4 Graphical illustration of the process capability indices for average waiting times of patients for the first diagnostic test in the Specialist Hospital. Source: own work in the Statistica program of "StatSoft" Company. 
1. The way of organizing work in a hospital;

2. Competence of doctors;

3. The work of nurses;

4. Sanitary conditions in the hospital;

5. Hospital equipment: medical devices, etc.

This card allows you to determine non-compliance in the sample compared to the size of a sample, the sample size must be constant (in the study sample consisted of 10 randomly selected patients discharged from the hospital that day for a 27 working days). Questionnaires were analyzed by identifying those in which one response was negative (Table 5). The average number of questionnaires for the period 1 month amounted to about 3 . The card can be noted that the results in the first half of the month was relatively better (Fig. 5, Table 6). The mean values of individual tests often remained below the central line. This could be due to the cast on call nursing, medical and lower medical personnel, such as ward attendants. Visualization of the results on the card can help you capture some irregularities and their gradual elimination. In the capture of certain recurring phenomena, however, it will be needed to conduct systematic research.

Table 5 Survey releases of patients who were discharged from the Specialist Hospital. Source: own work.

\begin{tabular}{|c|c|c|c|}
\hline $\begin{array}{c}\text { Test's } \\
\text { number }\end{array}$ & $\begin{array}{c}\text { Number of } \\
\text { questionnaires } \\
\text { with negative } \\
\text { response }\end{array}$ & $\begin{array}{l}\text { Number of all } \\
\text { questionnaires }\end{array}$ & $\begin{array}{c}\text { Questionnaires } \\
\text { fraction of } \\
\text { negative } \\
\text { responses }\end{array}$ \\
\hline 1 & 3 & 10 & 0.30 \\
\hline 2 & 2 & 10 & 0.20 \\
\hline 3 & 2 & 10 & 0.20 \\
\hline 4 & 3 & 10 & 0.30 \\
\hline 5 & 4 & 10 & 0.40 \\
\hline 6 & 2 & 10 & 0.20 \\
\hline 7 & 3 & 10 & 0.30 \\
\hline 8 & 2 & 10 & 0.20 \\
\hline 9 & 5 & 10 & 0.50 \\
\hline 10 & 3 & 10 & 0.30 \\
\hline 11 & 2 & 10 & 0.20 \\
\hline 12 & 2 & 10 & 0.20 \\
\hline 13 & 1 & 10 & 0.10 \\
\hline 14 & 2 & 10 & 0.20 \\
\hline 15 & 2 & 10 & 0.20 \\
\hline 16 & 4 & 10 & 0.40 \\
\hline 17 & 3 & 10 & 0.30 \\
\hline 18 & 5 & 10 & 0.50 \\
\hline 19 & 4 & 10 & 0.40 \\
\hline 20 & 5 & 10 & 0.50 \\
\hline 21 & 3 & 10 & 0.30 \\
\hline 22 & 4 & 10 & 0.40 \\
\hline 23 & 6 & 10 & 0.60 \\
\hline 24 & 7 & 10 & 0.70 \\
\hline 25 & 3 & 10 & 0.30 \\
\hline 26 & 1 & 10 & 0.10 \\
\hline \multirow[t]{2}{*}{27} & 4 & 10 & 0.40 \\
\hline & Total: & 270 & \\
\hline
\end{tabular}

\section{CONCLUSION}

One of the first steps in the implementation of SPC tools in the health care establishment should conduct training for both managers, supervisors, and other staff (Blakely, Lochner, \& Kawachi, 2002). Teaching methods and materials used for this purpose should be carefully planned so as not to discourage participants.
Table 6 A/B/C Zones analysis for survey releases of patients who were discharged from the Specialist

Hospital. Source: own work in the Statistica program of "StatSoft" Company.

\begin{tabular}{|c|c|c|}
\hline \multirow[t]{2}{*}{$\begin{array}{c}\text { Zones } \mathrm{A} / \mathrm{B} / \mathrm{C}: \mathbf{3 . 0 0 0} / 2.000 / 1.000 \\
\text { *Sigma } \\
\text { Tests for special causes (runs } \\
\text { rules) }\end{array}$} & \multicolumn{2}{|c|}{$\begin{array}{l}\text { Questionnaires fraction of negative } \\
\text { responses; Run Testes P Chart Center } \\
\text { Line: } 0.322 \text { Sigma } 0.148\end{array}$} \\
\hline & From sample & To sample \\
\hline 9 samples on same side of center & $\mathrm{OK}$ & $\mathrm{OK}$ \\
\hline 6 samples in row in/decreasing & $\mathrm{OK}$ & $\mathrm{OK}$ \\
\hline 14 samples alternating up \& down & $\mathrm{OK}$ & $\mathrm{OK}$ \\
\hline $\begin{array}{c}2 \text { or } 3 \text { samples in Zone A or } \\
\text { beyond }\end{array}$ & $\mathrm{OK}$ & $\mathrm{OK}$ \\
\hline $\begin{array}{c}4 \text { or } 5 \text { samples in Zone B or } \\
\text { beyond }\end{array}$ & OK & $\mathrm{OK}$ \\
\hline 15 samples in Zone C & OK & $\mathrm{OK}$ \\
\hline 8 samples beyond Zone $\mathrm{C}$ & $\mathrm{OK}$ & $\mathrm{OK}$ \\
\hline
\end{tabular}

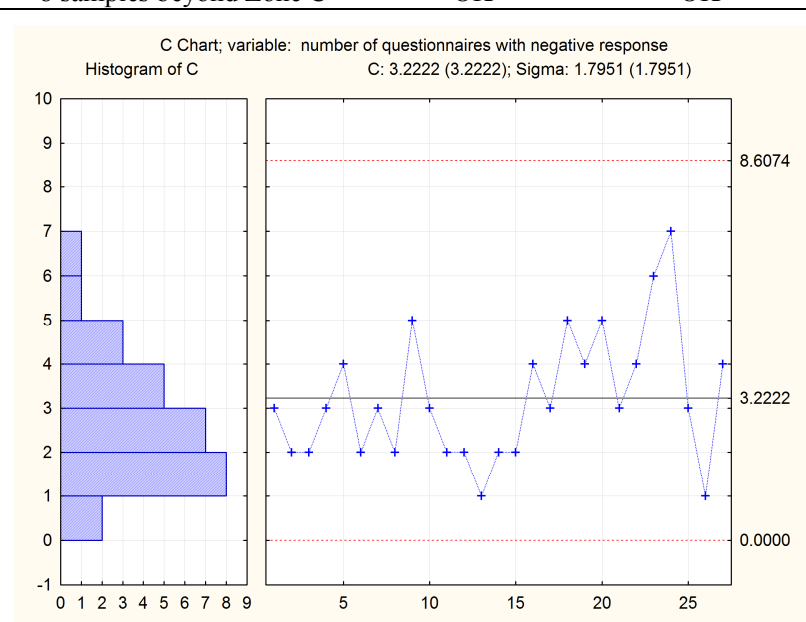

Fig. 5 Alternative value control card for survey releases of patients who were discharged from the Specialist Hospital. Source: own work in the Statistica program of "StatSoft" Company.

The use of statistics and other quantitative methods do not always control the process and not from any need to go into the complex theory.

By the implementation of SPC tools, including control charts, it should be consulted:

- Training should be continuous and took various forms,

- Directing the implementation of the programs should be led by a specialist within the organization;

- Start with small projects and learn by acquiring knowledge and experience;

- SPC techniques to implement in parallel with other methods of quality control;

- Recourse to external consultants;

- Continued emphasis on improving the quality, not just the desire to control;

- The philosophy of continuous improvement is to contribute to a thorough analysis of control charts, and the results were used for the next step on the road to perfection;

- There are signals and significant or specific reasons for encouragement to solve problems and understand the importance of quality improvement;

- Employees should not feel depressed and dislikes related to the implementation of tasks assigned to them;

- Quality policy has conducted and the organization has developed a quality system (Wall et al., 2005). 
- Potential benefits of SPC in institutions providing medical services include:

- Minimize losses due to the systematic identification and analysis of key processes in health services and the direct control of the associated root causes of problems;

- Support the concept of preventive actions to replace the control measures aimed merely at fault detection;

- Task delegated to the operating personnel (such as average medical staff);

- Emphasizing the need to promote the concept of quality management at all levels of the health care institution;

- Supporting the creating an atmosphere of active and collaborative problem solving (consolidation of medical environments, nursing);

- Opportunity to fine monitor the quality of work performed by all (quality as a result of the involvement of the entire team for the good of patients);

- Establishing a common language for patients and minimize the resulting confusion guarantees;

- Minimize the cost of sample testing and inspections (Curtis et al., 2006; Duclos et al., 2010).

Thus, in many cases, the SPC can be a complementary element for ensuring proper system of monitoring processes in health services.

\section{References}

Antoñanzas, F., Juárez-Castelló, C. A., \& Rodríguez-Ibeas, R. (2016). Improving health care systems by building 'more Europe'. The European Journal of Health Economics, 1-3. article. https://doi.org/10.1007/s1019 8-016-0791-4

Baji, P., García-Goñi, M., Gulácsi, L., Mentzakis, E., \& Paolucci, F. (2015). Comparative analysis of decision maker preferences for equity/efficiency attributes in reimbursement decisions in three European countries. The European Journal of Health Economics, 1-9. article. https://doi.org/10.1007/s10198-015-0721-x

Benneyan, J. C., Lloyd, R. C., \& Plsek, P. E. (2003). Statistical process control as a tool for research and healthcare improvement. Quality \& Safety in Health Care, 12(6), 458-64. https://doi.org/10.1136/qhc.12. 6.458

Blakely, T. a, Lochner, K., \& Kawachi, I. (2002). Metropolitan area income inequality and self-rated health--a multi-level study. Social Science \& Medicine (1982), 54(1), 65-77. https://doi.org/10.1016/S02779536(01)00007-7

Coast, J. (2009). Maximisation in extra-welfarism: A critique of the current position in health economics. Social Science and Medicine, 69(5), 786-792. https://doi.org/10.1016/j.socscimed.2009.06.026

Curtis, J. R., Cook, D. J., Wall, R. J., Angus, D. C., Bion, J., Kacmarek, R., ... Puntillo, K. (2006). Intensive care unit quality improvement: a "how-to" guide for the interdisciplinary team. Critical Care Medicine, 34(1), 211-218. https://doi.org/10.1097/01.CCM.00001906 17.76104.AC

Dahlgaard, J. J., Pettersen, J., \& Park, S. M. (2011). Quality and lean health care: A system for assessing and improving the health of healthcare organisations. Total
Quality Management \& Business Excellence, 22(March 2015), 673-689. https://doi.org/10.1080/14783363. 2011.580651

Detyna, B. (2011). Quality management in logistics. Support methods and tools. Examples, tasks (1st ed.). Walbrzych: Publishing House of the Angelus Silesius University of Applied Sciences.

Detyna, B. (2015). Monitoring of hospital logistics processes in the process of improving the medical services quality. Economic Studies. Scientific Papers of the University of Economics in Katowice, (249), 255270.

Detyna, B., \& Detyna, J. (2011). Quality of Medical Services. Statistical Evaluation. Methodological Proposal (1st ed.). Warszawa: Difin SA.

Duclos, A., Voirin, N., Touzet, S., Soardo, P., Schott, A.M., Colin, C., ... Lifante, J.-C. (2010). Crude versus case-mix-adjusted control charts for safety monitoring in thyroid surgery. Quality \& Safety in Health Care, 19, e17. https://doi.org/10.1136/qshc.2008.031799

Flynn, T. N., Louviere, J. J., Peters, T. J., \& Coast, J. (2010). Using discrete choice experiments to understand preferences for quality of life. Variancescale heterogeneity matters. Social Science and Medicine, 70(12), 1957-1965. https://doi.org/10.1016/ j.socscimed.2010.03.008

Giorgio, L. Di, Filippini, M., \& Masiero, G. (2015). Is higher nursing home quality more costly? The European Journal of Health Economics, 1-16. article. https://doi.org/10.1007/s10198-015-0743-4

Greiner, K. A., Li, C., Kawachi, I., Hunt, D. C., \& Ahluwalia, J. S. (2004). The relationships of social participation and community ratings to health and health behaviors in areas with high and low population density. Social Science \& Medicine, 59(11), 23032312. https://doi.org/10.1016/j.socscimed.2004.03.023

Guthrie, B., Love, T., Fahey, T., Morris, A., \& Sullivan, F. (2005). Control, compare and communicate: designing control charts to summarise efficiently data from multiple quality indicators. Quality \& Safety in Health Care, 14(6), 450-4. https://doi.org/10.1136/qshc. 2005.014456

Hamrol, A., \& Mantura, W. (2008). Quality management. Theory and practice. Warszawa: PWN.

Henderson, G. R., Mead, G. E., van Dijke, M. L., Ramsay, S., McDowall, M. a, \& Dennis, M. (2008). Use of statistical process control charts in stroke medicine to determine if clinical evidence and changes in service delivery were associated with improvements in the quality of care. Quality \& Safety in Health Care, 17(April 2002), 301-306. https://doi.org/10.1136/qshc. 2006.020784

Hewett, D. G., Watson, B. M., Gallois, C., Ward, M., \& Leggett, B. A. (2009). Intergroup communication between hospital doctors: Implications for quality of patient care. Social Science \& Medicine, 69(12), 17321740. https://doi.org/10.1016/j.socscimed.2009.09.048

Hinckley, C. M. (2003). Make no mistake-errors can be controlled. Quality \& Safety in Health Care, 12, 359365. https://doi.org/10.1136/qhc.12.5.359

Holli, K., Laippala, P., Ojala, a, \& Pitkänen, M. (1999). Quality control in health care: an experiment in radiotherapy planning for breast cancer patients after 
mastectomy. International Journal of Radiation Oncology, Biology, Physics, 44(4), 827-833.

Kusztina, E., Zaikin, O., \& Tadeusiewicz, R. (2010). The research behavior/attitude support model in open learning systems. Bulletin of the Polish Academy of Sciences: Technical Sciences, 58(4), 705-711. https://doi.org/10.2478/v10175-010-0075-6

Kwietniewski, L., Heimeshoff, M., \& Schreyögg, J. (2016). Estimation of a physician practice cost function. The European Journal of Health Economics, 1-14. article. https://doi.org/10.1007/s10198-016-0804-3

Lee, S. M., Lee, D., \& Olson, D. L. (2012). Health-care quality management using the MBHCP excellence model. Total Quality Management \& Business Excellence, 24(2), 1-19. https://doi.org/10.1080/14783 363.2012.728853

Litva, A., Coast, J., Donovan, J., Eyles, J., Shepherd, M., Tacchi, J., ... Morgan, K. (2002). "The public is too subjective": Public involvement at different levels of health-care decision making. Social Science and Medicine, 54(12), 1825-1837. https://doi.org/10.1016/ S0277-9536(01)00151-4

Lurie, J. D., Merrens, E. J., Lee, J., \& Splaine, M. E. (2002). An approach to hospital quality improvement. The Medical Clinics of North America, 86(4), 825-45. Retrieved from http://www.ncbi.nlm.nih.gov/pubmed/ 12365342

Łańcucki, J. (2003). Fundamentals of total quality management TQM. Poznań: Publishing House of the University of Economics.

Manning, D. M., O’Meara, J. G., Williams, A. R., Rahman, A., Myhre, D., Tammel, K. J., \& Carter, L. C. (2007). 3D: a tool for medication discharge education. Quality \& Safety in Health Care, 16(England LG-English DC20070215), 71-76. https://doi.org/10.1136/qshc. 2006.018564

Martin, G. P., Leslie, M., Minion, J., Willars, J., \& DixonWoods, M. (2013). Between surveillance and subjectification: Professionals and the governance of quality and patient safety in English hospitals. Social Science and Medicine, 99, 80-88. https://doi.org/ 10.1016/j.socscimed.2013.10.018

Mascia, D., Angeli, F., \& Di Vincenzo, F. (2015). Effect of hospital referral networks on patient readmissions. Social Science and Medicine, 132, 113-121. https://doi.org/10.1016/j.socscimed.2015.03.029

Muhlemann, A. P., Oakland, J. S., \& Lockyer, K. . (1992). Production and Operations Management (6th ed.). London: Pitman.

Munechika, M., Sano, M., Jin, H., \& Kajihara, C. (2014). Quality management system for health care and its effectiveness. Total Quality Management \& Business Excellence, 25(7-8), 889-896. https://doi.org/10.1080/ 14783363.2014 .906112

Nair, B. G., Peterson, G. N., Newman, S. F., Wu, W. Y., Kolios-Morris, V., \& Schwid, H. A. (2012). Improving documentation of a beta-blocker quality measure through an anesthesia information management system and real-time notification of documentation errors. Joint Commission Journal on Quality and Patient Safety, 38(6), 283-288.
Perkins, J. M., Subramanian, S. V, \& Christakis, N. A. (2015). Social networks and health: a systematic review of sociocentric network studies in low- and middle-income countries. Soc Sci Med, 125, 60-78. https://doi.org/10.1016/j.socscimed.2014.08.019

Rappange, D. R., van Exel, J., \& Brouwer, W. B. F. (2016). A short note on measuring subjective life expectancy: survival probabilities versus point estimates. The European Journal of Health Economics, 1-6. article. https://doi.org/10.1007/s10198-015-0754-1

Różewski, P., Zaikin, O., Kusztina, E., \& Tadeusiewicz, R. (2011). The motivation model for the intellectual capital increasing in the knowledge-base organization. Studies in Computational Intelligence, 381, 47-56. https://doi.org/10.1007/978-3-642-23418-7_5

Subramanian, S. V. (2004). The relevance of multilevel statistical methods for identifying causal neighborhood effects. Social Science and Medicine. https://doi.org/10.1016/S0277-9536(03)00415-5

Thompson, J. R., \& Koronacki, J. (2001). Statistical Process Control: The Deming Paradigm and Beyond (2nd ed.). London: Chapman and Hall/CRC.

Thor, J., Lundberg, J., Ask, J., Olsson, J., Carli, C., Härenstam, K. P., \& Brommels, M. (2007). Application of statistical process control in healthcare improvement: systematic review. Quality \& Safety in Health Care, 16(5), 387-99. https://doi.org/10.1136/ qshc. 2006.022194

Timmerman, T., Verrall, T., Clatney, L., Klomp, H., \& Teare, G. (2010). Taking a closer look: using statistical process control to identify patterns of improvement in a quality-improvement collaborative. Quality \& Safety in Health Care, 19(6), e19. https://doi.org/10.1136/ qshc. 2008.029025

Wall, R. J., Ely, E. W., Elasy, T. A., Dittus, R. S., Foss, J., Wilkerson, K. S., \& Speroff, T. (2005). Using real time process measurements to reduce catheter related bloodstream infections in the intensive care unit. Quality \& Safety in Health Care, 14(4), 295-302. https://doi.org/10.1136/qshc.2004.013516

Wickizer, T. M., Franklin, G., Fulton-Kehoe, D., Turner, J. A., \& et al. (2004). Patient Satisfaction, Treatment Experience, and Disability Outcomes in a PopulationBased Cohort of Injured Workers in Washington State: Implications for Quality Improvement. Health Services Research, 39(4), 727-748. https://doi.org/10.1111/j. 1475-6773.2004.00255.x

Wickizer, T. M., Franklin, G., Plaeger-Brockway, R., \& Mootz, R. D. (2001). Improving the quality of workers' compensation health care delivery: the Washington State Occupational Health Services Project. The Milbank Quarterly, 79(1), 5-33. https://doi.org/10.1 111/1468-0009.00194 